\title{
THE ROLE OF RELIGIOUS COURTS IN PROTECTING WOMEN'S RIGHTS IN DISTRIBUTION OF JOINT PROPERTY
}

\author{
Rasyidin $^{1}$, *Dian Eriani ${ }^{2}$, Ade Soraya ${ }^{3}$ \\ 1,2,3 Universitas Islam Kebangsaan Indonesia \\ E-mail: dianeriani04@gmail.com
}

\begin{abstract}
This study aims to review the discussion on how the role of the Religious Courts towards the protection of women's rights in the distribution of joint assets in the decision Number 4698/Pdt.G/2019/PA.Tgrs and also how the considerations of the Religious Court Judges based on the Decision Number 4698/Pdt.G/2019/PA.Tgrs. The research method used is normative juridical with a conceptual approach and a statutory approach. Data analysis uses a qualitative approach. The Religious Courts in protecting women's rights in cases of the distribution of joint property have a role and function to examine, adjudicate and decide on a case applying human rights values with respect for human dignity, non-discrimination, equality before the law, justice, benefit, legal certainty, and ex officio judges provide protection for women, by giving $70 \%$ of joint property to women and 30\% to men by ignoring the Marriage Law and the Compilation of Islamic Law. Consideration of judges who ignore women's rights and have a patriarchal mindset towards child support. It is the duty of a man to provide for his children, an obligation that is neglected causes a man to be able to collect wealth while a woman to provide a living for children is the cause of not being able to collect wealth. Judges should consider this to create legal justice.
\end{abstract}

Keyword: Religious Courts, Joint Assets, Women's Rights

\section{INTRODUCTION}

Human life on earth has been determined by the creator that life on this earth is in pairs. Humans were created with different sexes, namely male and female to coexist and produce offspring. Islam encourages to form a family and invites people to live in the auspices of the family, because the family is like a small picture in a stable life that becomes the fulfillment of human desires, without eliminating their needs.

The relationship that is bound by the name of Allah called marriage makes it lawful for a man and a woman to have a husband-and-wife relationship, so that a person can continue his offspring and carry on his life, in a household, with the aim of forming a happy household, namely the creation of a household. sakinah, mawaddah, warahmah, eternal and happy. As stated in Article 3 of the Compilation of Islamic Law (KHI), marriage aims to build a family life that is sakinah, mawaddah, and rahmah. According to Sudarsono, marriage is a noble and sacred contract between a man and a woman.

Article 1 of Law Number 1 of 1974 concerning marriage states that marriage is an inner and outer bond between a man and a woman as husband and wife with the aim of forming a happy and eternal family (household) based on God Almighty. Marriage does not only aim to realize outer happiness, but also aims to realize inner happiness because marriage is not only seen as a physical relationship, but also an inner relationship. However, the reality is that not all marriages can realize the purpose of marriage itself, even marriages often have to break up in the middle of the road. 
Dreams and hopes of the marriage are carried out forever until the death of one husband and wife, this is actually what Islam wants. In certain circumstances, there are things that require the termination of the marriage, in the sense that if the marital relations continue, then harm will occur. Islam justifies breaking up a marriage as the last step in continuing the household. Dissolving the marriage in that way is a good solution.

There are many reasons couples file for divorce both from women (divorced) and from men (talak divorce), the decision can arise due to several factors and conditions where it is no longer possible for a household to be maintained, for example, experiencing domestic violence. what was done by her husband, there is no longer compatibility, different principles, or because the husband is acting unfairly, so that if it is maintained it will do more harm than good. Article 115 of the Compilation of Islamic Law reads, divorce can only be carried out in front of a court session, and if the court concerned has tried and failed to reconcile the two parties. For parties who are Muslim, then the authority to resolve these problems is the Religious Courts, while for other religions refer to the District Courts. Sociologically-realistically, people who are Muslim accept the authority of Islamic law and obey Islamic law.

In the divorce process, whether it is a divorce divorce or a lawsuit, it will automatically have an impact on the assets obtained during the marriage period. The assets obtained while still having the status of husband and wife (in marital status), are called joint assets, or better known as gonogini assets. With regard to joint property, it is very important to resolve the matter until a mutual agreement is reached, with the aim of obtaining the best agreement for the ex-husband and wife and their children, if only in that marriage they have children and children from subsequent marriages.

Before discussing in detail the topic in this article, the author will describe the general concept of joint property first. Joint assets are property or assets obtained during marriage apart from gifts or inheritance. Joint assets can be in the form of tangible and intangible objects, as Article 85 of the Compilation of Islamic Law states that "the existence of joint property in marriage does not rule out the possibility of property belonging to each husband and wife". The distribution of joint property must be in accordance with the law and not be distributed arbitrarily, the distribution of joint property is regulated in Law Number 1 of 1974 (Marriage Law) and regulated in the Compilation of Islamic Law, where if there is a dispute between husband and wife then the dispute brought to the Religious Courts.

The division of joint property is only one of the many cases handled by the Religious Courts which prove the need for attention in protecting the interests of women. The decisions issued by the judges on these claims are certainly directly related to efforts to protect the interests and rights of women. The Religious Courts is a formal institution based on Islamic law which has the mission of realizing the benefit of society. The law will affect matters of marriage, divorce, reproductive rights, rape, and violence against women. The authority of the Religious Courts in the field of marriage has a lot to do with the interests of women in resolving cases.

Religious Courts As the executor of judicial power, it is a hope for the community, especially women, for these institutions to be able to enforce the law for the fairest possible justice. Religious Courts are required to apply the law by taking into account the existing facts. Judges of the Religious Courts are expected to be able to pay attention to the burdens borne by women and protect the rights of those who are victims of the behavior of husbands who do not carry out their responsibilities. The decisions that arise from these cases are expected to be able to fulfill the rights of women in return for the suffering they feel. The existence of violations of women's human rights, of course, requires 
us to study and identify which laws are in accordance with our sense of justice and women's human rights and which laws are not. Discrimination against women in the legal field is contained in three aspects at once, namely the legal material (content of law), legal culture (culture of law) and legal structure (structure of law). It is very important to know to what extent we have anticipated legal developments that guarantee and provide high respect and respect for women's human rights.

The existing law has not been able to accommodate these various problems, the cause is classic because the realm of women is still considered too domestic so that law enforcement is still weak and gender unfair. Article 229 of the Compilation of Islamic Law emphasizes: "Judges in resolving cases submitted to him must pay serious attention to the legal values that live in society, so that their decisions are in accordance with a sense of justice." That is, the judge's decision must be contextual, not merely referring to the text of the Act by him, the judge is required to be fair, to exert all his reasoning abilities in resolving a case before him.

Religious Courts must pay special attention to efforts to empower women who in the family are often victims, weak parties and are under the domination of men. Even though Indonesia is a legal state, sometimes the interests of women are neglected, the reason is sometimes classic, namely that women are only housewives and men are the head of the household. Enforcing a regulation and protecting women's rights in divorce requires the role of judges in a decision. Women's rights which have been guaranteed in the constitution and specifically women's rights due to divorce are contained in the Marriage Law Number 1 of 1974 and the Compilation of Islamic Law.

The Tigaraksa Religious Court in its decision number 4698/Pdt.G/2019/PA.Tgrs has handed down a decision in the case of joint property in which the Plaintiff (ex-wife) has more role in collecting joint assets seen from the number of courts as well as housekeeper than the Defendant (exhusband). What is the role of the Religious Courts in their decisions and considerations. Departing from the problems above, it encourages the author to write articles related to the role of the religious courts in protecting women's rights in the distribution of shared assets with the focus of the study leading to the decision Number 4698/Pdt.G/2019/PA.Tgrs. There are two main issues that the author will describe in this study, namely regarding the role of the Religious Courts in protecting women's rights in the distribution of joint assets in the decision Number 4698/Pdt.G/2019/PA.Tgrs and also how the considerations of the Religious Court Judges based on Decision Number 4698 /Pdt.G/2019/PA.Tgrs.

\section{RESEARCH METHOD}

This research is a normative juridical research, in which it discusses the doctrines or principles in the science of law. This study uses a statute approach which is carried out by examining laws and regulations related to the legal issues under study, in this case to see the content of the Law which is used as a source of law by the Judge as a consideration in making decisions. The conceptual approach departs from the views and doctrines that develop in legal science, researchers here will find ideas, legal concepts that are relevant to the issues at hand, doctrines, and concepts that will then become a reference for the author in building legal arguments to resolve the issue or object of study under study.

Sources of legal materials used in this study are secondary legal materials which include primary legal materials, secondary legal materials and tertiary legal materials. The technique of collecting legal materials is carried out by library research by reading, citing, recording, and understanding various literatures related to the object of research, in the form of primary legal 
materials, secondary legal materials, and tertiary legal materials and document studies. Meanwhile, the analysis of legal materials in this study uses a qualitative approach, in this case each data obtained is then systematically arranged for further analysis, in order to obtain a comprehensive picture of the symptoms and facts contained in the problem under study. Furthermore, conclusions are obtained using the deductive method, which is a way of thinking that starts from general things to then draw specific things by using provisions based on general knowledge such as theories, arguments or principles to draw conclusions that are specific.

\section{RESULT AND DISCUSSION}

In connection with the description of the case which is the focus of this study, the author will first begin the description of the discussion by describing the course of the case. As the data obtained by the author in the field, the plaintiff on behalf of Sofi Roselinda, SE, MM, Akt., C.A bint Dr. Ir. Sofyan P. Warsito with his lawsuit dated September 16, 2019 has filed a joint property lawsuit that has been registered with the Registrar of the Tigaraksa Religious Court with register Number 4698/Pdt.G/2019/PA.Tgrs, as for the Defendant Deni Candra, S.Kom., S. Si bin Moedjiono. In line with that, the marriage between the Plaintiff and the Defendant has been terminated due to divorce (Divorce sue) in accordance with the decision of the Sleman Religious Court No. 561/Pdt.G/2012/PA.Smn. dated December 18, 2012, in which the decision has permanent legal force and the Deed of Divorce No. 106/AC/2013/PA. sm. dated January 28, 2013. In addition, during the marriage between the Plaintiff and the Defendant, they had 1 daughter, which from the divorce decision to the joint property lawsuit, the child was in the care and care of the Plaintiff, as her biological mother without being given maintenance by the Defendant; Meanwhile, during the marriage period between the Plaintiff and the Defendant, joint assets (gono-gini) have been produced, including a plot of land on which a permanent building stands in accordance with the Certificate of Ownership No. 05280 on behalf of Deni Candra (Defendant) and Sofi Roselinda (Plaintiff). For the process of acquiring land and buildings, they obtained through a credit facility from Bank Mandiri for 10 years, starting from May 2008 to May 2018, at which time the land and buildings have been paid off. In addition, the litigating party also owns a plot of land on which a permanent building stands, the land is in accordance with the Certificate of Ownership in the name of Deni Candra (Defendant).

With regard to the control of all joint assets (gono-gini), since the divorce between the Plaintiff and the Defendant, the joint property is controlled by the Defendant. In addition, in the case of the collection of joint assets and also for household needs between the Plaintiff and the Defendant, the Plaintiff who plays a more role as the wife in the household, so it is considered unfair if the distribution of joint assets (gono-gini) applies Article $97 \mathrm{KHI}$, which is divided into equal parts for the Plaintiff and the Defendant. Therefore, Article 97 of the KHI must be understood that joint property can be divided into 2 (two) between husband and wife if all the household needs of the Plaintiff and Defendant from marriage to divorce are met by the Defendant as the head of the household and the Plaintiff's role as a housewife. who only work to take care of the household and take care of the children. The Plaintiff in his petition pleads with the Judge, so that the Plaintiff is entitled to get 3/4 (three quarters) of the share, and the Defendant gets 1/4 (quarter) of the property, so that the application of the article is not correct.

In connection with the description of the case above, the judge decided to grant the Plaintiff's claim to the convention in part, and determined that as joint property (gono gini) the Plaintiff of the 
convention and the Defendant of the convention was $46 \%$ of the value of the property, in the form of a plot of land on which a permanent building was located. Jalan Hanjuang Blok J3 / No. 32, RT. 10, RW. 01, BSD City Sector 1-1 Griya Loka, Rawa Buntu Village/kelurahan, Serpong District, South Tangerang City, Banten Province, with a Land Area of 235 M2 (two hundred and thirty five square meters), according to Certificate of Ownership No.05280 on behalf of Deni Candra (Defendant of the convention) and Sofi Roselinda (Plaintiffs of the convention), with the following limits:

- In the north it is bordered by the house of Ida's mother/Mr. Wily

- To the south, it is bordered by Jalan Hanjuang Raya;

- To the east, it is bordered by the house of Mr. Thomas;

- To the west it is bordered by Rike's mother's house;

In addition, the judge also determined that the Convention Plaintiff's share and the Convention Defendant's share of the joint property in dictum 2 is for the Convention Plaintiff to get a share of $70 \%$ and the Convention Defendant to get a $30 \%$ share of $46 \%$ of the value of the joint property. And the judge also sentenced the Convention Defendant to divide and hand over the joint property in dictum 2 to the Convention Plaintiff in the amount of $70 \%$ of the Convention Plaintiff's share and $30 \%$ of the Convention Defendant's share of $46 \%$ of the value of the property, and if it cannot be divided in kind, the joint property is in selling the auction in public at the State auction office and the result is that $70 \%$ of the $46 \%$ value of the property is handed over to the Convention Plaintiff and $30 \%$ becomes part of the Convention Defendant.

The panel of judges who examined and tried this case with their authority, have fulfilled the rights of women arising from the dissolution of marriage or divorce such as the distribution of joint assets, as stated in Article 97 of the Compilation of Islamic Law which reads: joint property as long as it is not specified otherwise in the marriage agreement", in this case the panel of judges overruled the provisions in Article 97 of the Compilation of Islamic Law, because the application of the provisions of Article 97 of the Compilation of Islamic Law in the a quo case, if it is related to the participation of the Plaintiff in the convention as the wife, then judged to be inaccurate and unfair, so that in determining the parts of the Plaintiff to the convention and the Defendant to the convention, the Panel of Judges will consider the sense of justice in accordance with Article 5 of Law Number 48 of 2009 in conjunction with Article 229 of the Compilation. In the decision, it is clear that the panel of judges tried the Plaintiffs of the convention so that they got a $70 \%$ share and the Convention Defendants got a $30 \%$ share of $46 \%$ of the value of the joint property. The judge has issued a decision other than that determined by the Compilation of Islamic Law to meet the interests of women, but the decision is only part of the joint property of the plaintiff's lawsuit.

Based on Islamic law by adhering to the principles of justice and expediency "The court or judge is the implementer of law enforcement (upholders of the rule of law) which one of its functions is to develop human rights values. ${ }^{1}$ In line with this principle, the judge's decision in this joint property case has not fully played a role in fulfilling the rights of the Convention Applicant/Reconvention Respondent in the case examination process. The judge ruled out the Plaintiff as a woman who has no obligation to provide for the children, this has been stated by the Plaintiff in her answer that the Defendant as a father has never provided costs/support for the needs

1 Yahya Harahap, Hukum Acara Perdata Tentang Gugatan, Persidangan, Penyitaan, Pembuktian, dan Putusan Pengadilan, (Jakarta: Sinar Grafika, 2005), hlm. 854. 
of the Plaintiff's and Defendant's children, so that in this case the Plaintiff finally sufficed all the needs of the child, from care, education, health and so on. Therefore, considering that the child's needs for the future are getting bigger, while the Defendant as a father has never provided a living for his child, the judge does not consider that providing a child's support by paying installments is the same as joint property, because the Plaintiff must provide for the child resulting from a marriage with The Defendant should be the Defendant's obligation, so that what the Plaintiff does as a woman is of no value.

During the divorce until the lawsuit is submitted to the Religious Court, the Defendant lives comfortably and occupies the house which is the joint property of the Plaintiff and the Defendant without providing rent for the house, while the Plaintiff and the Plaintiff's child cannot live in their own house, but can only live in the house. Plaintiff's parents house. In this case, the judge ignored the suffering felt by a woman as the plaintiff, that for a woman it is not easy after having children, she still lives with her parents.

As stated by the Plaintiff, that in the continuity of the household of the Plaintiff and the Defendant, and also in terms of the collection of joint assets and also for household needs between the Plaintiff and the Defendant, the Plaintiff's role as the wife in the household, where the Plaintiff's income is greater than to the Defendant. So that household needs are met by the Plaintiff, where in this case all household needs should be borne by the husband (Defendant) which is his obligation, this refers to the provisions of Article 34 of Law no. 1 of 1974 concerning the Marriage of Jo. Article 80 paragraph (2) Compilation of Islamic Law.

Based on the judge's decision, judges should, in adjudicating cases related to women and dealing with the law, must consider gender equality and gender stereotypes, as contained in the laws and regulations and unwritten regulations, in accordance with article 7 paragraph 1 Perma no .3 of 2017. In this case, the judge must explore the values that live in the community and local wisdom to achieve justice in the decisions issued, considering that the living provided to children is not the obligation of the plaintiff in meeting household needs, as well as former the husband is also obliged to give kiswah to his ex-wife in accordance with the compilation law of Islamic law and permaculture No. 3 of 2017.

Judges as implementers of law enforcement, there are two main functions that must be played by judges, namely as guardians of the independence of community members and as community guardians. ${ }^{2}$ In line with that, judges as guardians of the independence of community members, namely to develop human rights values in all fields, in this case judges are required to understand and understand, and apply human rights values, such as the protection of children, women, the UN Declaration of Human Rights, and others. . Judges have the function of developing human rights keywords in implementing law enforcement in the following ways, namely:

a. To take steps to defend and protect human rights,

b. To guarantee the protection of the human rights of the defendant and the plaintiff,

c. To recognize every human rights value inherent in each individual or group,

d. To respect every human rights inherent in every individual or group,

e. Improving (to promote) the quality of human rights protection in all aspects of law enforcement and life. ${ }^{3}$

2 Yahya Harahap, Op.Cit., hlm. 854-855.
${ }^{3}$ Ibid. 
The steps as described above are carried out by the judge with the aim of examining, adjudicating, and deciding, so as to produce justice without compromising the rights of the litigants in court. In the case of judges who are gender biased, justice for women's rights is difficult to find in each of their decisions. Whereas if it leads to the conception of judges as actors of the judicial power of the Court, then in fact they carry out 3 functions, namely:

1. Conducting the judiciary carefully and appropriately, namely according to the SOP that has been set in the procedural law by receiving, examining and adjudicating and resolving cases.

2. Provide fair legal services to justice seekers during the process of receiving and examining cases and post-decision services.

3. Enforce law and justice in cases submitted to him through quality decisions. ${ }^{4}$

In addition to some general descriptions of joint property cases as described above, there are also other problems. Where the posita 4.1 assets obtained during the marriage between the Convention Plaintiff and the Convention Defendant are 55 installments worth Rp 204,658,520. What is categorized as joint property (gono gini) is a down payment plus interest on the loan, while the remaining installments are 65 times with a total of Rp. 241,869,160 until the installments are paid off, paid by the Convention Defendant and including the property of the Convention Defendant, in this case if calculated based on a percentage, the acquisition of the common property of the Convention Plaintiff and the Convention Defendant is $46 \%$ of the total value of the house price, while the remaining 54\% belongs to the Defendant.

In these considerations it appears that the panel of judges ignores the interests of women, it is natural that the defendant pays the remaining installments of 65 times, because after the divorce the plaintiff did not live in the house, meanwhile the Plaintiff who played a role in providing for the children, in that condition the Defendant ignored his obligations as stated mandated by law. In other words, the Plaintiff's income is intended for the needs of the child, not to pay the installments. Here the judge does not consider the efforts made by the plaintiff as a woman to provide for the children, that this is the same as paying the installments for the house.

Based on the judge's consideration, the participation and contribution of the Convention Plaintiff is proven to be greater in obtaining joint property number 4.1. In this case, the decision of the panel of judges will deviate from the provisions of Article 97 of the Compilation of Islamic Law where in the event of a divorce the husband and wife will get half or 50\% of the value of the joint property, due to the application of the provisions of Article 97 of the Compilation of Islamic Law in the a quo case, if it is connected with the participation of the Plaintiff of the convention as the wife, is not appropriate and unfair, so that in determining the part of the Plaintiff of the convention and the Defendant of the convention, the Panel of Judges will consider the sense of justice which refers to the provisions in Article 5 of Law Number 48 of 2009 in conjunction with Article 229 of the Compilation of Islamic Law. The consideration is very gender perspective, where the judge is of the view that women are housewives and have no obligation to earn a living, and basically there is no mixing of husband's property and wife's property, because as marital status is in accordance with article 86 of the Compilation of Islamic Law, to fulfill the rights of the husband and wife. women by adhering to the principles of justice and expediency.

The application of the provisions of the Act is the first basis that a judge needs to do in deciding a case before him. The judge must seek, find, and determine whether there is a law regarding the

\footnotetext{
${ }^{4}$ Asni, Op. Cit, hlm 23.
} 
disputed case, then the judge analyzes it. If the provisions of the existing law conflict with the public interest, propriety, humanity, and a sense of justice, the judge may and has the authority to take counter-legem actions, namely taking decisions that are contrary to the articles in the law concerned. ${ }^{5}$ Therefore, every person or community who feels persecuted, where their rights begin to collapse, then the judiciary, through the hands of the judge, provides protection by enforcing the law based on a fair decision. The function and role of the judge here is as a provider of protection for people who are persecuted. ${ }^{6}$ Judges are given the authority to put forward the reasoning of justice, without having to be trapped in the textual application of the law but contrary to the embodiment of the principle of justice.

If we refer to women's rights before the courts, then based on Perma Number 3 of 2017 it adds to the understanding of judges in fulfilling women's rights in court, where there is a breakthrough in the Religious Courts/Syar'iyah Court in protecting women's rights, so that the rights of women are minimized. women's rights are not neglected, of course, it needs the participation of all parties to realize these goals. Decisions that are in accordance with women's perspectives need to be developed not only for divorce, but also for cases relating to the distribution of joint property, inheritance, and so on.

In line with the above description, critical feminist jurists argue that the movement of the judiciary is very phalloccentric (in male dominated), ${ }^{7}$ in this case the law and legal officers are mostly controlled by men, so that the decisions made in the courts are very gender biased and do not heed the rights of women. If it refers to the judge's consideration who is of the opinion that the marriage between the Convention Applicant/Reconvention Respondent and the Convention Respondent/Reconvention Applicant, if maintained, will bring about greater mafsadat than the benefits that will be achieved, including prolonged mental suffering received by the Plaintiff because there is no the good faith of the Defendant to settle the distribution of joint assets by deliberation. The judge's consideration has a patriarchal mindset and is not based on a gender perspective, resulting in a decision that ignores the Defendant's obligation to provide for the child. The verdict represents a statement from Simone de Beauvoir, where men build a legal world based on their imagination and make it confusing. ${ }^{8}$

The resulting considerations reflect men's values, which then have an impact on other groups that are not represented in these values. ${ }^{9}$ The judge in this case did not consider the feelings of the Plaintiff who felt tired, and was burdened with raising his own child without the Defendant's role in the child's development, the Plaintiff also felt pressured because the Defendant ignored when asked to share the assets produced during the marriage. A lesson can be learned from the decision in that case, that gender sensitivity is important for judges, because the social and cultural side of women is in a weak position, so it is the judge's responsibility to lift women from adversity towards equality between women and men to get justice. ${ }^{10}$ In this case, men are tasked with protecting women, historically

${ }^{5}$ Ibid., hlm. 858-856.

${ }^{6}$ Yahya harahap, Op. Cit., hlm 855.

${ }^{7}$ Otje Salman dan Anton F.Susanto, Teori Hukum: Mengingat, Mengumpulkan dan Membuka Kembali, (Bandung: Refika Aditama, 2015), hlm 132.

${ }^{8}$ Niken Savitri, Op.Cit., hlm 27.

${ }^{9}$ Ibid

${ }^{10}$ Asni, Op.Cit., hlm 26. 
because men are competitive and have personal interests, on the other hand women are understanding and caring. ${ }^{11}$

\section{CONCLUSION}

The Religious Courts in protecting women's rights in cases of the distribution of joint property have a role and function to examine, adjudicate and decide on a case applying human rights values with respect for human dignity, non-discrimination, equality before the law, justice, benefit, legal certainty, and ex officio judges provide protection for women, by giving $70 \%$ of joint property to women and $30 \%$ to men by ignoring the Marriage Law and the Compilation of Islamic Law.

Consideration of judges who ignore women's rights and have a patriarchal mindset towards child support. It is the duty of a man to provide for his children, an obligation that is neglected causes a man to be able to collect wealth while a woman to provide a living for children is the cause of not being able to collect wealth. Judges should consider this to create legal justice.

\section{REFERENCE}

Abdul Manan, Aneka Masalah Hukum Perdata Islam Di Indonesia, (Jakarta: Kencana Prenadamedia Group, 2011).

Ali Yusuf As-Subki, Fiqh Keluarga Pedoman Berkeluarga dalam Islam, (Jakarta: Amzah, 2012).

Amir Syarifuddin, Hukum Perkawinan Islam di Indonesia Antara Fiqh Munakahat dan UndangUndang Perkawinan, (Jakarta: Kencana, 2011).

Amiur Nuruddin dan Azhari Akmal Tarigan, Hukum Perdata Islam Indonesia, (Jakarta: Kencana Prenadamedia Group, 2004).

Amran Suadi, Peranan Peradilan Agama Dalam Melindungi Hak Perempuan Dan Anak Melalui Putusan Yang Memihak dan Dapat Dilaksanakan, Jurnal Hukum dan Peradilan, Vol. 7, No. 3 (2018).

Asni, Kontekstualisasi Hukum Berperspektif Perempuan Di Peradilan Agama, Jurnal Al-‘Adl, Vol. 9 No. 2, (2016).

Defi Uswatun Hasanah, "Hak-Hak Perempuan Dalam Putusan Pengadilan Agama: Studi Perbandingan Hukum Keluarga Islam Dan Konvensi CEDAW,” Tesis, Magister Universitas Islam Negeri Syarif Hidayatullah, Jakarta, (2017)

Indonesia, Intruksi Presiden Nomor 1 Tahun 1991, Tentang Penyebarluasan Kompilasi Hukum Islam.

Niken Savitri, HAM Perempuan Kritik Teori Hukum Feminis terhadap KUHP, cet. I, (Bandung: Refika Aditama, 2008).

Otje Salman dan Anton F.Susanto, Teori Hukum: Mengingat, Mengumpulkan dan Membuka Kembali, (Bandung: Refika Aditama, 2015).

Peter Mahmud Marzuki, Penelitian Hukum, Edisi Revisi, (Jakarta: Kencana, 2005).

Sudarsono, Hukum Perkawinan Nasional, (Jakarta: Rineka Cipta, 2005)

Yahya Harahap, Hukum Acara Perdata Tentang Gugatan, Persidangan, Penyitaan, Pembuktian, dan Putusan Pengadilan, (Jakarta: Sinar Grafika, 2005).

Zainuddin Ali, Metode Penelitian Hukum, (Jakarta: Sinar Grafika, 2015).

${ }^{11}$ Otje Salman dan Anton F.Susanto, Op.Cit., hlm. 133. 
Volume 1 No 2 (2021)

The Role Of Religious Courts In Protecting Women's Rights In Distribution Of Joint Property DOI: $10.54443 /$ ijerlas.v1i2.115 